\title{
Profetiese bediening: die Woord en sy hoorders
}

\author{
H.F. van Rooy \\ Dept. Klassieke en Semitistiek \\ Potchefstroomse Universiteit vir $\mathrm{CHO}$ \\ POTCHEFSTROOM
}

\begin{abstract}
Prophetic ministry: the Word of God and its hearers

Ministers of religion are trained to speak. to proclaim the good new's in preaching and in counselling. They must be able to communicate, but communication can only be successful when the hearer of the proclaimed Word has internalized that W'ord. This paper explores the meaningfulness of preaching in the light of research demonstrating that the traditional style of preaching sometumes presented a very poor form of communicalion. The interaction between prophet and audience in the Old Testament is studied and conchusions are drawn from this for modern preachers. A mumister must know the circumstances of his congregation, but must also iny to ascertain what the congregation's response to the preaching is. In the light of their response he can react to cerlain misconceptions regarding the implications of the gospel and proclaim a message that is fitting for the specific circumstances of the congregation.
\end{abstract}

\section{Inleiding}

Prediking moet verstaanbaar wees on sinvol te kan wees. Juis op grond van onverstaanbaarlieid, soos ten dele aangedui deur navorsing oor die effek van kerklike prediking op die hoorders, word die sin van kerklike prediking bevraagteken. Die vraag is al prontuit gevra deur Runia (1981) in 'n publikasie met die titel Heeft preken nog z $m$ ? Prediking het tog te doen met die verkondiging van God se Woord en die feit dat sy Woord geweldige betekenis vir die mens het, kan tog nie bevraagteken word nie. Die vraag is egter of die prediking Sondag in die kerk nog 'n doel het, om dit baie skerp te stel. In hierdie artikel word hierdie vraag ondersock, maar met 'n spesifieke invalshoek. Dit is duidelik dat geslaagde prediking 'n wisselwerking tussen prediker en gehoor moet bewerkstellig. Is prediking te dikwels 'n geval van eenrigtingverkeer? Kan daar iets gedoen word om werklik sinvolle kommunikasie tussen prediker en gehoor te bewerkstellig? Dit is trae wat aandag moet ontvang. In hierdie artikel word 'n Ou-Testamentiese perspektief op hierdie vrae gegee deur te let op die wisselwerking tussen 'n profeet en sy gehoor. Daama word enkele implikasies hiervan vir die Homiletiek aangedui 
'n Predikant word ook herder en leraar genoem. Predikante leer ander mense deur dit wat hulle sê - Sondag van die preekstoel, of wanneer hulle met kategese besig is, of met huisbesoek. Hulle moet ook praat wanneer hulle as herders mense troos wanneer 'n dierbare gesterf het, of wanneer hulle mense moet vermaan. Daar word dus nie verniet baie tyd daaraan gespandeer on voornemende predikante toe te rus om taal te kan gebruik nie. Teologiese studente moet leer om eksegese te doen en hulle moet leer on preke te maak. Word hulle egter ook geleer om nie net die teks te beheers nie, maar on ook die situasie te beheers waarin preke in die lewens van lidınate moet grondvat? Daarvoor is dit nodig dat predikante ook moet kan luister, dat daar ' $n$ wisselwerking tussen hulle en hulle lidmate moet wees. As prediking profetiese prediking moet wees, kan moderne predikante iets leer deur ag te slaan op die wyse waarop die wisselwerking gefunksioneer het tussen die Ou-Testamentiese profete en die gehoor tot wie hulle boodskap gerig was. In hierdie artikel word daar agtereenvolgens aandag gegee aan die preek en sy gehoor in die kerk, aan die wisselwerking tussen profete en hulle gehoor in die tyd van die Ou Testament en aan die wisselwerking tussen predikant en gemeente in die prediking. Wat die preek en sy gehoor betref, word aangedui dat dit 'n saak is wat in die Homiletiek besondere aandag geniet. Die saak van die wisselwerking tussen profete en hulle gehoor word ondersoek om vas te stel of die Ou-Testamentiese gegewens lig kan werp op die saak van modeme predikers en hulle gehoor.

\section{Die preek en sy gehoor: die vraag na die sin van prediking}

In gereformeerde kerke neem die prediking steeds 'n baie belangrike plek $\mathrm{m}$. In hierdie opsig is sulke kerke steeds navolgers van die Hervonning, veral as 'n mens met Runia (1981:7) saamstem dat die Hervorming tereg die herontdekking van die prediking genoem word. Dic belang van die prediking blyk ook uit die uitspraak van die Tweede Helvetiese Belydenis (vgl. Greidanus, 1989:9): praedicatio verbi Del est verbum Dei (die prediking van die Woord van God is die Woord van God). Aan die ander kant bly dit natuurlik belangrik om duidelik te onderskei tussen die Woord van God en die prediking daarvan (Helberg, 1983: 112). Daar moet ook onderskei word tussen die Woord as prediking en die Woord in die prediking. Die mens se prediking is alleen maar verklaring van die prediking as openbaring en is daarom steeds toetsbaar (Van der Walt, 1988:488). Daar is ' $n$ groot verskil tussen die predikers van die Bybel en die predikers van vandag. Die predikers van vandag ontvang nie die inhoud en inpretasie van hulle woorde direk van God nie, maar word geroep on kanale te wees vir God se Woord (Greidanus, 1989:7-8).

Prediking het te doen met kommunikasie, met die oordra van God se Woord aan die hoorders van vandag; die diens van die Woord kan nie losgemaak word van tussenmenslike kommunikasie nie (Lange, 1976:111). Daar is egter baie stemme wat opklink en sê dat prediking 'n verouderde vonn van kommunikasie is (vgl. 
Runia, 1981:10; Dingemans, 1991:21). Runia (1981:10) vestig die aandag op verskeie ondersoeke wat daarop wys dat die prediking weinig effek op die hoorders het (vgl. ook Dingemans, 1991:13-14). Egte komınunikasie is 'n saak van wederkerigheid en dit ontbreek in prediking. ' $n$ Preek is van nature ' $n$ saak van eenrigtingverkeer - en juis dit is baie mense se beswaar teen die tradisionele manier van preek (Thomas, 1978:12). Van wat gehoor word, word maar slegs $20 \%$ onthou (vgl. Schütz, 1981:44).

Daar word dus al hoe meer stemme gehoor wat sê dat die prediking in 'n krisis verkeer (vgl Eslinger, 1989:11). Hierdie siening hou ten dele verband daannee dat die predikers nie ' $n$ voldoende beeld van hulle hoorders het nie (Bolkestein, 1977:73). Die prediker moet leer om die regte vrae te vra aan sy teks en oor sy gehoor (Bright, 1977:176). Aan eersgenoemde word hopelik genoeg aandag gegee, maar laasgenoemde bly dikwels agterweè. Gebeur dit nie dat preke in 1994 gepreek word wat op dieselfde wyse in 1794 gepreek sou kon gewees het nie (vgl. Bolkestein, 1977:100)? Daarom is dit belangrik dat die rol van die hoorder in die prediking goed raakgesiell word (Dingemans, 1991:13).

Pieterse is 'n tipiese voorbeeld van icmand wat die prediking benader binne die raamwerk van 'n kommunikasiemodel. Hy wys op die verskil tussen wat hy noem die historiese model van kommunikasie (Pieterse, 1985:29), wat teruggevoer kan word na Plato en Aristoteles, en die modene model van kommunikasie. In die historiese model word daar aan drie elemente aandag gegee, naamlik die spreker, die toespraak en die gehoor (1985:30). In hierdie model word die hoorder dus wel betrek, maar bloot as teikell. Die prediker moet sy teiken ken sodat hy kan raakskiet en sy hoorder kan oortuig (Pieterse, 1985:32). Die groot swakheid van die model is volgens Pieterse (1985:32) dat dit 'in eenrigtingverkeer veronderstel en dat kommunikasie dus nie as 'n dinamiese proses beskou word nie.

Pieterse (1985:32-33) kontrasteer dan hierdie historiese model met 'n nuwere model van kommunikasie, waarin daar veel variasie is, maar wat alles verband hou met die werk van Kierkegaard. Kierkegaard se bydrae lê daarin dat hy die ontvanger beklemtoon het. Volgens Kierkegaard het kommunikasie eers plaasgevind as die ontvanger die boodskap vertolk het. Die historiese model is meer staties, terwyl daar 'n meer dinamiese model ontwikkel het, waarin daar plek is vir interaksie en terugvoer. Pieterse (1985:39) wil hierdie nuwe model met 'n balspel vergelyk, waar die bal heen en weer beweeg, terwyl die ou kommunikasiemodel met 'n pyl en boog vergelyk kan word. Pieterse wil selfs die sender en ontvanger op dieselfde vlak plaas, iets wat natuurlik die vraag na die gesag van die prediking dadelik aan die orde stel. Daar kan geen plaasvervanger wees vir Bybelse prediking wat uitgaan van die gesag van die Woord en wat op grond van die gesag van die Woord die gesagvolle verkondiging van die Woord daarstel nie (vgl. Bright, 1977:162-166). Hierdie aspek maak dit egter soveel te meer nodig dat die prediker ook sy gehoor moet ken. Eksegese van die Skrif moet aangevul 
word deur 'eksegese' van die gehoor (Bright, 1977:176). Pieterse (1985:119) beklemtoon dat 'n goeie spreker ook 'n goeie luisteraar is. As daar geen terugkoppeling is nie, kan kommunikasie misluk omdat mense die boodskap verkeerd kan interpreteer of weier om te luister (Pieterse, 1985:166).

In die nuwe kommunikasiemodel word aanvaar dat die hoorder aktief by die luisterproses betrokke is en dat sekere sake 'n invloed uitoefen op die hoorder se hoor en verstaan van 'n preek. Een saak wat 'n invloed uitoefen, is die hoorder se voorverstaan voor die kommunikasieproses (Pieterse, 1991:105). 'n Boodskap wat hiermee bots, sal maklik deur die hoorder verwerp word. So byvoorbeeld sal 'n gereformeerde gelowige wat 'n preek oor die verwerping van die kinderdoop hoor van ' $n$ predikant met ' $n$ doperse agtergrond, die preek nie aanvaar en imneem nie. Daar is ook empiries vasgestel dat hoorders relatief min van 'n preek imneem en onthou, al gebeur dit ook dat dit wat die hoorder hoor, steeds 'n invloed op hoin het, al kan hy nie alles direk weergee nie (Pieterse, 1991:118). Die gebruik van 'n sinvolle kommunikasiemodel kan die homiletiek in die algemeen en die prediking in die besonder net ten goede kom. Tog moet daarteen gewaak word dat 'n kommunikasiemodel gebruik word wat die gesag van die Woord en die gesag van die prediking kan ondermyn.

Dingemans (1991:141-152) onderskei drie soorte kommunikasie, naamlik lineêre kommunikasie, sirkulêre kommunikasie en interaktiewe sumboolkommunikasie. Lineère kommunikasie is onder andere die vorm wat in die tradisionele prediking gebruik is waar die sender sy boodskap aan die ontvanger oordra. Lineêre kommunikasie word egter ook gebruik deur koerante, radio en televisie, waar daar nie werklik sprake van gesprek tussen sender en ontvanger kan wees nie. In sirkulêre kommunikasie wissel die rol van senders en ontvangers voondurend, soos in gewone gesprekke. Pastorale gesprekke is ook goeie voorbeelde hiervan. Dingemans meen self (1991146) dat die interaktiewe simboolkommunikasie baie geskik is vir die prediking. Hier word veronderstel dat die spreker en hoorders gesamentlik betrokke is by die saak waaroor gepraat word. So het die kerkgangers en die predikant 'n primêre verhouding en kommunikasie met God (Dingemans, 1991:149). Die hoorders kom dus met sekere verwagtinge na die kerk en die prediker moet daannee rekening hou. Dingemans (1991:150-151) wys daarop dat daar binne hierdie benadering eintlik sprake is van 'n drievondige kommunikasieproses: die predikant kommunikeer met die Bybelteks en so eintlik met God; die hoorders kommunikeer deur middel van die liturgie met God en die Bybel op grond van hulle ervaring met die evangelie en met God, en die predikant poog on kommunikasie te bewerkstellig tussen die hoorders ell die Bybelse boodskap deur die preek. Hierdie drievoudige kommunikasie dien daartoe om die hoorders se verhouding inet God te verdiep en te verbreed.

In die genoemde kommunkasiewyse is dus steeds drie panye teenwoordig, naamlik God, die prediker en die gehoor. In die volgende afdeling word gewys 
op die profetiese proses, waarin daar ook van drie partye sprake is, naamlik, God, die profeet en die gehoor.

Saam met Runia (1981:53-54) sal gereformeerdes steeds van mening wees dat die prediking 'n onmisbare en onontbeerlike deel van die samekoms van 'n gemeente is. Daar moet egter besil word oor die problematiek dat baie hoorders min inneem van wat gepreek word en dat min verandering in die lewens van gelowiges direk aan die prediking toegeskryf kan word. Natuurlik word aanvaar dat die Heilige Gees deur die prediking werk en dat Hy baie dinge deur die prediking doen ten spyle van die predikers. Dit ontneem egter nie die prediker die verantwoordelikheid om sy voorbereiding vir die prediking ernstig op te neem en om in die proses aandag te gee aan hoe dit wat hy sê, deur die gemeente ervaar en geinternaliseer word nie. Predikante loop dikwels die gevaar on die kuns van luister af te leer (Pieterse, 1985:119). In die lig hiervan kan die wyse waarop die profete in die tyd van die Ou Testannent in wisselwerking met hulle gelıor gestaan het, nuwe lig bied op die wisselwerking ussen 'n predikant en sy gemeente vandag.

\section{Profete en hulle gehoor}

Profete was mense wat God se Woord in hulle eie tyd aan die mense van hulle tyd moes verkondig. Vir 'n profect was dit self vall die grootste belang on te weet dat hy 'n opdrag van God ontvang het wat hy nie anders kon as om uit te voer nie (vgl. Odendaal, 1985:8). Hierdie woord wat 'n profeet moes gaan verkondig, was altyd verbonde aan 'n konkrete historiese situasie, sodat 'n profeet nie maar 'n verkondiger van tydlose waarhede was ne (Odendaal, 1985:17): hy moes 'n spesifieke reaksie van God op spesifieke situasies in Israel verkondig (Achtemeier, 1973:63). Die verkondiging deur die profete was dus telkens 'n boodskap vir die hede. Selfs wamneer profete wel oor die toekoms gepraat het, was dit nie die toekoms ter wille van die toekoms nie, maar ter wille van die bekering of bemoediging van hulle hoorders (Greidanus, 1989:232). 'n Profeet het dus gesag gehad, maar die gesag was geleë in die woord wat hy moes verkondig (Greidanus, 1989:2). Greidanus (1989 229) noem die profetiese woord 'n woord vall God oor (jod

Profete het dus God se Woord telkens in 'n nuwe situasie gebring. Daar kan sekere groot lyne in die profete se boodskap opgemerk word. Hulle sluit ook aan by die tradisies van hulle volk, maar die tradisie word gebruik om die moedeloses te bemoedig en om die mense te konfronteer wat selftevrede is. So word die gemeenskap van die tyd van die profeet op 'n profetiese wyse gekonfronteer (Goldingay, 1990:129).

In hierdie gerigtheid op die mense van hulle tyd moes die profete telkens kennis neem van die verwagtinge en vrese van die volk, maar ook van hulle onderwerping aan of verwerping van die goddelike boodskap. Von Rad (1975:265) toon 
aan dat by die profete van die Babiloniese en Persiese tyd 'n meer intense verhouding tussen die profete en hulle gehoor opgemerk kan word. Hulle gehoor was grotendeels krities, selfs skepties, en as die profete gehoor wou word, moes hulle dit in gedagte hou. Daarom het die profete baie sterk daarna gestreef om deur hulle gehoor verstaan te word Hulle het probeer om wanopvattings uit die weg ruim, die volk te oortuig en om hulle argumente logies te stel.

In die werke van die profete van die tyd na die ballingskap kan meermale iets gelees word van die reaksie van die inense op die profetiese woord. In Haggai 2:3 staan byvoorbeeld: "Wie is onder julle nog oor wat hierdie huis in sy vroeëre heerlikheid gesien het? En hoedanig sien julle dit nou? Lyk dit nie soos niks in julle oë nie?" (OAV). Hier het Haggai waarskyulik die gevoel van die volk verwoord wat hulle self nie eers wou uitspreek nie (Von Rad, 1975:282). Hy vertolk hulle moedeloosheid oor die onderneming wat hulle aangepak het met die herbou van die tempel, asook iets van die meningsverskil wat daar onder die volk oor die herbou van die tempel was.

Haggai se optrede was gerig op reaksie van sy hoorders - reaksie in die vorm van aandag aan die tempel en die herbou daarvan (Mason, 1990:191). Ook in Sagaria kan iets van die prediking van die profete van die tyd na die ballingskap opgemerk word: 'n band word gelê tussen die verwagtinge van 'n profeet en 'n volk wat maklik sinies sou kon word oor die vervulling van die profetiese verwagting (Mason, 1990:234). In die profetiese boodskap word die volk gewys op dit wat reeds vervul is en daardeur op die sekerheid van die toekomstige vervulling van die verwagtinge. Maleagi se boodskap wys vir predikers vandag dat die grootste guns wat hulle hulle hoorders kan bewys, is om nie net te waarsku en te vermaan nie, maar om hulle geloof op God te rig (Mason, 1990:256). Mason (1990:260) toon aan dat die profete van die tyd na die ballingskap uit 'n pastorale hoek bekommerd was oor die mense van hulle tyd. Hulle het voortdurend te doen gehad met die bedreiging van ' $n$ verlies aan geloof, of apatie teenoor die geloof weens teleurstelling en ontnugtering.

In die profetiese proses kan drie belangrike partye onderskei word, naamlik God, van wie daar 'n boodskap kom, die profeet wat die boodskap oordra en die gehoor tot wie die boodskap gerig is (vgl. Overholt, 1977:132-133). Wat veral belangrik is, is die wisselwerking tussen hierdie drie partye. Wamneer 'n profeet 'n boodskap aan sy gehoor bring, kan die gehoor die boodskap aanvaar of verwerp. Wanneer die boodskap verwerp word, kan die profeet sy boodskap aanpas by die verwagtinge van sy gehoor, of hy kan op een of ander wyse sy boodskap bevestig. In die vorige afdeling is gewys na die drievoudige kommunikasieproses in die predikingaksie, soos deur Dingemans onderskei Dit is merkwaardig hoe hierdie drie aspekte presies net so in die profetiese proses na vore kom soos deur Overholt onderskei. 
Profete was deur God gestuur om sy Woord oor te dra aan sy volk - en soms ook aan ander mense as sy volk. Dit is van hierdie Woord dat God deur Moses vir die Israeliete gesê het dat dit naby hulle is, in hulle mond en in hulle hart (Deuteronomium 29:12). Toe die Here vir Jeremia geroep het, het Hy vir hom gesê: "Ek lê my woorde in jou mond." Die profete het dus 'n verpligting gehad om die woord oor te dra, sodat 'n profeet nie losgemaak kon word van sy eie ontmoeting met God nie (Childs, 1989:124). Die profete moes dus met die volk praat - en hulle het baie gepraat. 'n Pragtige voorbeeld van 'n profeet wat God se Woord bring, word in Jeremia 7 aangetref. Daar word verhaal hoe die profeet Jeremia onverskrokke by die tempel van die Here in Jenusalem gaan staan het en hardop God se Woord verkondig het. Hy het sy hoorders die waarheid onverdoeseld vertel. Dit was 'n woord van oordeel, 'n woord wat die mense nie wou hoor nie. Hulle moes hoor dat die tempel waarop hulle vertrou het, afgebreek gaan word. Hulle het gehoop dat daar sou vrede wees, maar Jeremia verkondig oordeel. Dit was 'n geval waar die mense sou kon sê: hier praat 'n profeet. Of hulle nou wou hoor of nie wou hoor nie, hy het gepraat Jeremia het homself direk gestel teenoor die verwagtinge, die ideologie van die mense en dit ontmasker. Hulle ideologie was dat Jerusalem en die tempel onaantasbaar was - en Jeremia het daardeur 'n streep getrek. Sy gehoor sou sy optrede alleen maar as hoogverraad kon ervaar (Brueggemann, 1988:74)

Tog het die profete mie net gepraat nie. Van Jeremia lees ons dat hy dikwels nie wou praat nie, dat hy met God geworstel het oor sy roeping wat soms vir hom te veel was. Hy sê self in Jeremia 20 dat daar tye was toe hy probeer het om die Here se woord vir homself te hou. maar dan het dit in hom gebrand soos ' $n$ vuur (Van Selms, 1972:257-258). Hierdie stryd van Jeremia met God toon duidelik wat dit werklik beteken om 'n profeet van God te wees, watter spanning dit teweegbring (Childs, 1989:128). Jeremia moes praat, of hy wou of nie. On te praat was die werk van die profete, maar hulle het ook goed geluster.

'n Mens tref iets van hierdie luisterhouding by Jeremia self aan. In Jeremia 7 verkondig hy die vernietiging van die tempel, maar daarin kan ook bemerk word hoe hy geluister het na wat die volk te sê gehad het. In vers 4 haal hy woorde aan wat onder die volk in omloop was en wat selfs deel van die tempelliturgie kon gewees het (Brueggemann, 1988:75). Hulle was sekerlik bekommerd oor die toekoms in die lig van die geweldige Babiloniese bedreiging wat daar in daardie tyd was. Hulle het luulleself egter getroos deur te sê: 'Die Here se tempel is hier by ons in Jerusalem.' Hulle het vertrou dat die Here hulle sou bewaar omdat hulle sy volk was en ondat sy tempel in Jerusalem was. Jeremia het dit gehoor en daarop gereageer toe hy gepraat het. Hulle mooi woorde was vals, dit was leuens, omdat hulle lewens radikaal verkeerd was. Hulle moes ophou om op die tempel te vertrou en hulle moes lutle bekeer

By die profect Esegiël tref' 'n mens dit dikwels aan dat hy sekere uitdrukkings wat sy gehoor gebruik het, aanhaal Hulle het dinge gesê op grond waarvan hy kon 
aflei hoe hulle op die Here se Woord gereageer het - en dan het hy weer op hulle reaksie gereageer. Esegiël het as profeet opgetree in Babilonië. Hy was self een van die ballinge wat koning Nebukadneser na Babilonië weggevoer het toe koning Jojagin aan Nebukadneser oorgegee het toe hy Jerusalem die eerste keer beleër het (2 Konings 24:10-16). Ongeveer tien jaar later het Nebukadneser Jerusalem ingeneem nadat hy dit 'n tweede keer beleër het en toe die stad en die tempel verwoes het (2 Konings 25:1-10), soos Esegiël en Jeremia voorspel het. Tussen die twee innames moes Esegiël aan die ballinge sê dat hulle nie na hulle eie land sou terugkeer nie - en hulle wou nie daardie boodskap hoor nie (Greenberg, 1983:230). Hierdie toedrag van sake kan afgelei word uit twee uitdrukkings wat die volk gebruik het en wat in Esegiël 12 aangehaal word. In vers 21 staan daar dat die volk 'n sekere uitdrukking gebruik het as reaksie op Esegiël se profesie dat Jenusalem vernietig gaan word: "die dae gaan voort en van al die gesigte kom niks nie" (OAV). Hierdie segswyse beteken dat die volk Esegiël se boodskap verwerp het (Zimmerli, 1979:281). Hulle het Esegiël se boodskap nie aanvaar as God se Woord vir hulle nie. Volgens hulle eie verwagtinge was 'n boodskap van verlossing eerder gepas en dit het hulle daartoe gebring on Esegiël se boodskap te verwerp. Die profeet se reaksie was om in opdrag van God sy woord te bevestig. In vers 27 volg dan 'n tweede spreckwoordelike uitdrukking: "Die gesig wat hy sien, is vir baie dae, en hy profeteer van tye wat ver is" (OAV). Hiermee word wel erken dat Esegiěl se woorde waar mag wees, maar die vervulling daarvan lè so ver in die toekoms dat die volk hulle nie daaraan gaan steur nie (vgl. Greenberg, 1983:230-231). Hierop is Esegiël se reaksie weer om die woord te bevestig en om die volk daarop te wys dat sy woorde spoedig in vervulling sal gaan.

Toe hulle wel naderhand begin glo het dat dit gaan gebeur, is hulle gevoelens verwoord deur 'n spreekwoord wat Esegiël in Esegiël 18 aanhaal: "Die vaders eet groen druiwe en dan word die kinders se tande stomp." Met hierdie spreekwoord het hulle hulleself verontskuldig. Hulle was nou in die ellende, maar dit was nie hulle skuld nie, dit was hulle pa's en oupa's wat nie wou hoor nie en nou ly hulle daaronder (vgl. Greenberg, 1983:327-328). Esegiël het dit gehoor en daarom troef hy hulle deur te verkondig dat elke mens self verantwoording moet doen vir sy eie lewe. As jy verkeerd doen, kan jy nie agter ander wegkruip nie.

Later in dieselfde hoofstuk kla die ballinge dan verder. Hulle het gesê: Die Here tree nie reg op nie. Hienmee word bedoel dat die volk die Here se optrede nie kan verstaan nie (Klein, 1979:107), dat dit arbitrêr en sonder koers is (Greenberg, 1983:333). Dit is 'n verskriklike aanklag teen God - en Esegiel het dit gehoor. Daarom gooi hy hulle beskuldiging na hulleself terug: dit is nie God wat verkeerd optree nie, dit is hulle wat nie reg optree nie en daarom is hulle onder die oordeel

Die profete het geluister - en nie net wanneer die volk 'n valse vertroue gehad het of hulleself verontskuldig het nie. Hulle het ook geluister wanneer dic mense 
moedeloos word in moeilike onstandighede. Toe die mense na die ballingskap uit Babiloniè na hulle eie land teruggekeer het, het hulle baie moeilike omstandighede ondervind. Daar was vyande rondom hulle, hulle was ann en is ook deur ' $n$ droogte geteister. In daardie tyd moes hulle as 'n klomp ann mense die Here se tempel herbou wat deur Nebukadneser vemietig is. Dit was harde werk. Hulle was ook teleurgesteld in dit wat hulle kon doen. Sou arm mense 'n tempel kon bou wat vir die Here goed genoeg is? Salomo se tempel was so mooi dat hulle poginkie maar sleg afgesteek het. In daardie tyd het die profete Haggai en Sagaria onder die volk opgetree - en albei het hierdie toon van moedeloosheid waargeneem. Haggai het gevra: Wie van julle het gesien hoe mooi die vorige tempel was? Hoe lyk die een vir julle? Daar was dalk nog enkele ou mense wat die vorige tempel gesien het en ook hulle was erg moedeloos (vgl. Van Rooy, 1988:57). Vir hierdie moedelose mense het Sagaria gesê dat hulle nie die dag van klein dingetjies gering moet ag nie (Sag. 4:10), terwyl Haggai hulle daarop gewys het dat die tempel nog 'n pragtige gebou sou word (Hag. 2:9). Ook die moedeloosheid is raakgesien en daarvoor het die profete 'n bemoedigende woord gehad.

Die profete het dus ook goed geluister. Hulle het nie geluister met die doel om hulle boodskap aan te pas by dit wat die mense wou hoor nie. Dit was maklik om 'n gewilde profeet te wees en net te sê wat die mense wou hoor. 'n Voorbeeld hiervan word in 1 Konings 22 aangetref. Josafat van Juda en Agab van Israel wou saam gaan veg teen die Arameërs. Daar was 400 profete wat vir hulle gesê het dat hulle maar kan gaan veg. Daar was egter nog 'n profeet met die naam van Miga. Agab het gesê dat Miga altyd net slegte dinge voorspel, maar Josafat wou hom hoor. 'n Boodskapper is na Miga gestuur en hy het vir Miga gesê om iets goeds te voorspel, maar Miga het gesê dat hy net kan sê wat God hom opdra om te sê. Om goed te luister beteken nie dat die boodskap aangepas moet word by wat die mense wou hoor nie, maar wel dat die boodskap aangepas moes word sodat die mense hoor wat hulle moes hoor op so 'n manier dat dit hulle direk raak.

Uit die gedeeltes wat bespreek is, is dit duidelik dat daar 'n gesonde wisselwerking tussen die profete en hulle gehoor was. Die profete het geweet wat in die harte van die volk geleef het - goed of sleg - en kon dan in hulle boodskap daarby aansluit on sodoende vir die mense die woord te bring wat hulle nodig gehad het. Die mense wou soms die woord ignoreer, hulle het soms teen die profete opgetree, soos wat Jeremia evaar het. Hulle kon egter nie anders as om tot 'n keuse te kom nie.

\section{Die wisselwerking tussen predikant en gemeente in die prediking}

Dat die prediking die Woord van God na die gemeente moet bring, staan steeds vas. Natuurlik is dit nie 'n eenvoudige saak nie. Die Woord van God wat in die Bybel opgeteken is, moet op 'n verantwoordelike wyse nuut aan die gemeente in 
hulle situasie verkondig word sodat die gemeente in die prediking God se Woord sal hoor (vgl. Odendaal, 1985:19). In hierdie proses moet die gemeente in hulle spesifieke situasie betrek word. In die historiese kommunikasiemodel waarna verwys is, het die gemeente ook 'n plek gehad as die teiken waarop die Woord gemik word. Dit het van die prediker 'n tweeledige kennis vereis: van die Woord en van die gemeente. Die prediker moes die Woord en die gemeente bymekaar bring sodat God met die gemeente praat in hulle konkrete lewensomstandighede (Van der Walt, 1988:501).

Die verkondiging mag ook nie die gemeente onaangeraak laat nie, maar moet die gemeente tot 'n duidelike keuse verplig (Van der Walt, 1988:504). Daar moet dus twee duidelike fases in die hele henneneutiese proses verloop (Dreyer, 1989 362). Die eerste is die eksegetiese of dekoderingskomponent: daarin gaan die eksegeet na die teks toe om op die ou end deur die teks self aangespreek te word Dreyer (1989:262) meen dat die prediker deur die woordgebeure tot dieselfde kommunikasie-ervaring met God as die oorspronklike lesers of hoorders korn. Dit is wel ' $n$ vraag of dit moontlik is om presies dieselfde te ervaar as die oorspronklike lesers. Dit sal eerder moontlik wees om te probeer vasstel wat die boodskap vir die oorspronklike hoorders of lesers was, alhoewel daar steeds 'n mate van onsekerheid bly, ondat die modeme eksegeet hom nie ten volle in die skoene van die oorspronklike hoorders of lesers kan plaas nie. Vir Dreyer (1989:362) is die tweede fase on die kommunikasie-ervaring van die homileet te enkodeer sodat die gemeente gelei kan word tot dieselfde kommunikasie-ervaring met God. Hierdie ervaring is nie noodwendig emosioneel nie (Dreyer, 1989:363). Wat belangrik is, is dat die konkrete situasie van die gemeente aan die orde moet kom (Dreyer, 1989.367).

Dreyer se benadering spreek duidelik uit die definisic wat hy vir prediking gee $(1989: 365)$ :

Prediking is ' $n$ pneumatologiese woordgebeure, waarin ' $n$ geroepe bedienaar van die Woord, via 'n kommunikasie-ervaring met 'n Skrifteks, die gemeente in hulle konkrete situasie begelei tot 'n ontmoeting met die lewende God.

In Dreyer se benadering word 'n belangrike plek gegee aan die werking van die Heilige Gees, wat natuurlik in die hele aangeleentheid van prediking die beslissende rol speel. Dit ontneem egter nie die prediker die verantwoordelikheid on sy opdrag so uit te voer dat sy werk bruikbaar vir die Heilige Gees is nie. Die prediker se taak is nie maar afgehandel as hy die Woord afgelewer het me. Hy moet, ook in die lig van wat in die vorige afdeling gesê is oor die wisselwerking tussen profete en hulle gehoor, probeer vasstel of die woord wat hy verkondig het, verstaan word en in die lewens van sy gemeente ingedring het. Wanneer die mens die woord hoor, word hy opgeroep tot beslissing (Pieterse, 1989:595). Die prediker moet ook seker maak dat sy prediking wel die mense tot beslissing 
oproep en op grond van hulle beslissing moet hy die verkondiging van die Woord opvolg met verdere bevestiging of verheldering indien daar onbegrip was.

In die proses is dit belangrik om te onthou dat die hoorder wel 'n plek in die prediking het. Schütz (1981:176) verwys na die Mitspracherecht van die hoorder en sê dat die hoorder dit uitoefen selfs wanneer dit hoin ontsê word. Die hoorder se hoor word beinvloed deur die hoorder se wense en vrese, deur die nomne en sanksionerings van die groep waartoe hy behoort, deur sy eie instelling en vooroordele (Schïtz, 1981:193). Die vraag na die hoorder is 'n kengmatiese vraag. Daar is geen situasielose kerugna nie en geen beligting van die situasie sonder die kerugma nie (Schütz, 1981:182). Daarby moet in gedagte gelıou word dat die predikant en sy hoorders primêr 'n gesamentlike verhouding met God het (Dingemans, 1991:149) en bune hierdie gesamentlike band moet God se Woord aan die gemeente gebring word

Die prediker moet self ook onthou dat hy hom nooit ten volle kan losmaak van wie hy is en in watter tyd hy leef nie. Elke prediker staan in 'n tradisie, maar hy mag nie daarin stol nie. Hy moet telkens in nuwe omstandighede 'n relevante boodskap bring. Hy moet sy gehoor ken, maar dan nie as teiken vir die prediking nie. Hy moet ook weet hoe die gehoor op die prediking reageer, om sodoende weer by 'n volgende geleentheid op hulle reaksic te reageer.

Om prediking te verander van blote eenrigtingverkeer na 'i proses waarin behoorlike kommunikasie plaasvind, is verskillende nuwe vorme van prediking al eksperimenteel beproef. Rumia (1981) wy's op 'n aantal aanbiedingsivyses waarmee al geëksperimenteer is on die prediking te vervang. Een moontlikheid is byvoorbeeld om net op Skriflesing te konsentreer (Runia, 1980:40-41). Die prediking het egter 'n eie gerigtheid, waardeur die boodskap persoonlik op die hoorder gerig word. Die Skrif vra ook na vertolking. Die gemeente leef vandag in 'n ander tyd met ander omstandighede as die oorspronklike lesers. 'n Preek het steeds 'n dubbele funksie: uitleg en transponering, en aktualisering van die boodskap vir vandag. 'n Tweede poging is die vervanging van die preek inet 'n gesprek (Runia, 1981:42-43). Die gesprek word dan 'n saamsoek na wat die evangelie vir vandag beteken, soos in Bybelstudie. Runia wys egter daarop dat die gesprek wesentlik van 'n preek verskil. In 'n gesprek kan iemand nie iemand anders die heil van God meedeel nie.

In plaas daarvan om prediking met iets anders te vervang, is daar ook al verskillende pogings aangewend om die vorm van die preek aan te pas sodat dit nie net 'n saak van eenrigtingverkeer is nie. Een moontlikheid is om die preek aan te vul met 'n soon dialoog tussen die predikant en die gemeente na die preek (Runia, 1981:45; vgl. ook Schïtz, 1981 41). Dit is egter baie moeilik in 'n groot gemeente, met 'n goeic kans dat net dicselfde mense telkens aan die bespreking sal deelneem. 'n Ander moontlikheid is om geleentheid te gee dat die preek onderbreek kan word met vrae en opmerkings van die kant van die gemeente (Runia, 
1981:45). Die probleem is dat dit moeilik spontaan kan gebeur. 'n Derde moontlikheid wat Runia bespreek, is dialoogprediking (Runia, 1981:46). Dit het sekere winste, maar is ook nie geslaag nie, omdat dit baie voorbereiding verg vir die twee persone daarby betrokke, omdat alle predikante nie daarvoor geskik is nie en dit nie ' $n$ egte oplossing bied vir die preek as monoloog nie.

Runia oordeel self negatief oor hierdie moontlikhede, maar vermeld ' $n$ paar oplossings wat wel ondersoek kan word (Runia, 1981:46-48; vgl. ook Schütz, 1981: 41 en Pieterse, 1985:131-133). Die sake wat hy noem, het veral 'n belang vir die analise van die gehoor. Die eerste moontlikheid is 'n voorgesprek tydens die preekvoorbereiding met 'n aantal gemeentelede. Die mense kan dan korreksies aanbring op verkeerde indrukke van die prediker oor die gemeente en hierdie voorgesprek kan ook ondersoek instel na die gemeente se voorverstaan van die teks. 'n Tweede moontlikheid is 'n nagesprek in die week na die preek gelewer is of direk na die prediking. Dit kan dieselfde mense as by die voorgesprek betrek, maar die groep moet verteenwoordigend van die gemeente wees. In hierdie gesprek kan daar terugvoering verkry word om te bepaal hoe die preek by die hoorders tuisgekom het en hoe hulle die boodskap verstaan het. 'n Derde moontlikheid is variasie in die tweede diens se vonn en inhoud, wat in die geval van die kerk waartoe Runia behoort, moontlik geword het weens die afskaffing van Kategismusprediking, waaroor Runia self jammer is. Rumia (1981:51) meen dat die grootste probleem met preke is dat daar nie 'n dialoog ontstaan tussen die boodskap van die teks en die lewe van die gelowige nie. Dic probleem is soms dat 'n preek ook vir die predikant 'n Abrahamitiese ervaring is: hy vertrek sonder om te weet waarheen hy gaan (Runia, 1981:54)

Eslinger (1989:13) verwys na drie nuwe benaderings tot die prediking: die induktiewe benadering, die narratiewe benadering en 'n benadering wat direk wil aansluit by die vorm en beweging van die Bybelse teks. In die narratiewe benadering word 'n teks nie gepreek op die ou manier nie, maar 'n storie word vertel wat 'n Bybelse boodskap verwoord (vgl. Eslinger, 1989:21-23). Die induktiewe benadering is ' $n$ reaksie teen die deduktiewe benadering, wat teruggevoer kan word na Aristoteles (Eslinger, 1989:95). In die deduktiewe benadering word daar beweeg van 'n algemene waarheid na 'n spesifieke toepassing daarvan. 'n Tema word geformuleer en in punte uitgewerk (Eslinger, 1989:95). In die induktiewe metode word daar besondere aandag aan die hoorders gegee (Eslinger, 1989:111112). In hierdie benadering is daar twee duidelike fokuspunte, naamlik die hoorders en hulle persoonlike en sosiale konteks en die Bybelse teks in sy historiese, teologiese en literêre inhoud (Eslinger, 1989:114). In die derde metode word aangesluit by die Bybelse narratiewe vonn, in aansluiting by die teks self (Eslinger, 1989:136-138). Die nadeel is dat hierdie metode net geskik is vir narratiewe gedeeltes van die Bybel 
Hierdie drie metodes kan natuurlik op baje punte ensstig gekritiseer word, maar hulle onstaan hou verband met leemtes in die tradisionele benadering tot die prediking, waarin die gemeente maklik onbetrokke gelaat kan word. In die herevaluering van die prediking in die gereformeerde tradisie sal daar minstens met die leemtes van die tradisionele benadering rekening gehou moet word. Prediking wat die hoorders onbeweeg laat, kan nie reg laat geskied aan die verkondiging van God se Woord nie.

Vir die predikant moet die besef deurbreek dat die preek slegs een van 'n verskeidenheid kommunikasie-aangeleenthede in die gemeente moet wees (Runia, 1981: 56). Sonder kategese en pastorale sorg, sonder voortdurende kontak met sy gemeente, kan die predikant nie terugvoering kry oor sy prediking nie en kan daar nie 'n gesonde wisselwerking wees wat die verkondiging van die Woord ten goede sal wees nie. Persoonlike kontak en onderlinge vertroue is absoluut noodsaaklik on kommunikasie in die prediking te laat plaasvind (Pieterse, 1985:127). Hierdie standpunt oor komınunikasie in die prediking, wat deur onder andere Pieterse baie duidelik gestel is, word ondersteun deur die gegewens wat die $\mathrm{Ou}$ Testament bied oor die wisselwerking tussen 'n profeet en sy gehoor. Hierdie standpunt van Pieterse en andere hou verband met die kommunikasieteorieë wat hulle onderskryf. Bunne dieselfde kommunikasieteorie kan bemerk word hoedat die profete in die Ou Testament effektiewe kommunikasie laat plaasvind het deur baie goed rekening te hou met die reaksie van hulle gehoor met die oog daarop on te reageer op die verkeerde verwagtinge en persepsies van bulle gehoor. Soos wat die Ou-Testamentiese profete deur God geroep was om sy boodskap oor te dra, moet die moderne prediker dit ook doen. Soos wat die profeet nie sy boodskap by sy gehoor se verwagtinge moes aanpas nie, moet ook die modeme prediker die Woord verkondig, soms teen weerstand in.

\section{Slot}

'n Predikant moet tussen sy mense beweeg en hoor wat hulle sê - en luister na die gesindheid, bekommernis, vrese en verwagtings wat agter die mense se woorde sit. As 'n predikant se taak tot praat beperk word, gaan hy spoedig bloot in die lug praat. Wanneer hy goed geluister het, sal hy so kan praat dat sy woorde tussen sy mense grondvat en nie maar by die een oor in en by die ander oor uit is nie. In die verkondiging van die Ou-Testamentiese profete is dit duidelik dat hulle goed geluister het - en dat hulle daarom met hulle woorde die gehoor kon tref. So moet ook die modeme prediker weet wat in die harte van sy hoorders leef, anders kan sy boodskap in die lug bly hang.

\section{Bibliografie}

ACHTEMEIER, E R 1973 The Old Testament and the Proclamation of the Gospel Philadelphia Westminster Press 
BOLKESTEIN, MH. 1977. Zo word er gepreekt Verslag van een onderzoek naar de communicatievormen in 89 preken. 's-Gravenhage : Boekencentrum

BRIGHT, J 1977. The Authority of the Old Testament. Grand Rapids : Baker

BRUEGGEMANN, W 1988. To Pluck up, to Tear down A Commentary on the Book of Jeremiah Grand Rapids : Eerdmans. (International Theological Commentary.)

CHILDS, B.S 1989. Old Testament Theology in a Canonical Context Philadelphia Fortress

DINGEMANS, G.D J. 1991. Als hoorder onder de hoorders Hermeneutische Homiletiek Kampen Kok

DREYER, T.F. 1989 . 'n Poging tot herdefinisie van van die prediking binne die raamwerk van die Reformatoriese teologie Hervormde Teologiese Studies, 45:350-369

ESLINGER, RL 1989 A New Hearing Living Options in Homiletic Method. Nashville Abingdon

GOLDINGAY, J 1990. Approaches to Old Testament Interpretation Updated edition Leicester : Apollos

GREENBERG, M. 1983 Ezekiel, 1-20 A New Translation with Introduction and Commentary Garden City, New York : Doubleday \& Co (The Anchor Bible)

GREIDANUS, S. 1989. The Modern Preacher and the Ancient Text Interpreting and Preaching Biblical Literature Grand Rapids Eerdmans

HELBERG, J L 1983. Verklaring en prediking van die Ou Testament Potchefstroom Potchefstroomse Teologiese Publikasies

KLEIN, RW 1979 Israel in Exile A Theological Interpretation Philadelphia Fortress Press (Overtures to Biblical Theology.)

LANGE, E 1976. Predigen als Beruf. Stuttgart Kreuz Verlag

MASON, R 1990 Preaching the Tradition. Homily and Hermeneutics after the Exile Cambridge : University Press

ODENDAAL, D H 1985 Die Ou-Testamentiese profete in die prediking. (/n Burger, C W , Muller, B A \& Smit, D J reds 1985. Riglyne vir prediking oor die protete (Woord teen die lig II/1 ) Kaapstad NG Kerk-Uitgewers p 7-20)

OVERHOLT, TW 1977 Jeremiah and the Nature of the Prophetic Process (/n Merrill, A L \& Overholt, T W eds Scripture in History and Theology Essays in Honor of J C Rylaarsdam Pittsburg Pickwick p 129-150)

PIETERSE, H JC 1985 Verwoording en prediking Pretoria NG Kerkboekhandel Transvaal

PIETERSE, H J 1989 Prediking en geloofservaring gesprek oor die teologiese gehalte van die preek Henormde Teologiese Sindies, 45:586-597

PIETERSE, H JC 1991 Gemeente en prediking Pretoria NG Kerkboekhandel

RUNIA, K 1981 Heeft preken nog zin' Kampen Kok

SCHUTZ, W 1981. Probleme der Predigt Gottingen Vandenhoeck \& Ruprecht (Dienst am Wort 41.)

THOMAS, J. 1978 Het luisten nauw Het gesprek over de preek tussen gemeente en predikant Kampen : Kok

VAN DER WALT, J J 1988 God werk deur die prediking in die geloofslewe 'n homiletiese sleutel vir die prediking Koers, 53 486-511

VAN ROOY, HF 1988 Eschatology and Audience The Eschatology of Haggai Old Testamem Essays, 1:49-63.

VAN SELMS, A. 1972 Jeremia I Nijkerk Callenbach (De Prediking van het Oude Testament)

VON RAD, G. 1975 Old Testament Theology 11 The Theology of Israel's Prophetic Traditions London SCM

ZIMMERLI, W 1979 Ezekiel I A Commentary on the Book of the Prophet Ezekiel Philadelphia Fortress Press (Hermeneia) Translator: R E Clements 